\title{
Variability in Mallomonas
}

\author{
By KATHARINE HARRIS \\ Department of Botany, University of Reading
}

(Accepted for publication 25 August 1966)

\begin{abstract}
SUMMARY
This paper deals with variability within certain species of the genus Mallomonas as revealed under the electron microscope. New varieties and two new species are described ( $M$. annulata; $M$. pillula), one of these having previously been considered a variety, partly through confusion. An attempt is made to consider different kinds of variability and to make a decision on what range can be tolerated within the limits of a species. The importance of examining the whole organism under the electron microscope as well as a few scales is now realized. It is desirable also to examine the flagellum since several species which have been described as belonging to the genus Mallomonas must be separated from it because they prove to have two flagella.
\end{abstract}

\section{INTRODUCTION}

In this paper I discuss different aspects of variability in the genus Mallomonas derived from working with wild material viewed with the light and electron microscopes. Some species have scales of a constant pattern, others show a series of easily separable varieties and one, $M$. pillula, has a series of forms all living together, which I refrain from classing as varieties from the material available. Some of these taxonomic units (e.g. M. annulata) are found in all sorts of habitats, but others seem to occur in only a few habitats which are of much the same kind. In addition there may be a range in the scales of a single organism. This is particularly noticeable in organisms of an elongated shape such as $M$. annulata. Also, while most scales of an individual may be perfectly formed, one may find a few scales that appear to be unfinished and these look very different; I have called them immature.

\section{DESCRIPTION OF SPECIES}

Mallomonas papillosa Harris \& Bradley 1957 and 1960

(Figs. 1, 2, 4; P1. 1, figs. 1, 2)

History. Harris \& Bradley (1957, in part), pl. 4, fig. 9 (replica of scale and bristle tip and foot). The description in the text and text-figures $\mathrm{H}, \mathrm{K}, \mathrm{L}, \mathrm{M}$, which we called Mallomonas papillosa, is now recognized as $M$. annulata.

Emended diagnosis. Cellula ellipsoides ferme, setis ubique contecta tenuibus, brevibus, curvatis. Squamae parvae, prope aequatae per totam cellulam; squama ovalis cum cupola, scuto, margine. Scuti pars exterior papillis aequaliter contecta, pars interior levis. Margo distalis costas exhibet obliquas. Cupola saepissime paucas papillas ferens in uno latere, permulata foramina minuta in altero. Setae paucis dentibus aequalibus instructae. Cystum leve obovatum, parte latiore saepissime anteriore. 
Dimensiones. Cellula $12-18 \mu$, squamae $3-4 \times$ prope $2 \mu$, cystum $10-11 \mu$ latitudine.

Emended English diagnosis. Cell broadly ellipsoidal, covered all over with delicate short curved bristles. Scales small, nearly uniform all over cell. Scale oval showing dome, shield and flange. Shield with regularly arranged papillae on the outer surface, inner surface smooth. Distal margin showing oblique ribs. Dome usually showing a few papillae on one side and numerous fine perforations on the other. Bristles showing a few evenly marked serrations. Cyst smooth, obovate, broad end usually anterior.

Occurrence. The type locality of Mallomonas papillosa (Harris \& Bradley, 1957, pl. 4, fig. 9) is Stan Lake (Nat. Grid, 480.0 E. 175.5 N.). The locality given in the text refers to the light-microscope drawings and description. Stan Lake is a slowly moving stream widened into an ornamental lake. It has now been greatly altered and $M$. papillosa has not been found there lately in quantity and the material described in this paper is from Benyons Lake (Nat. Grid, 464.0 E. 163.3 N.) where $M$. papillosa has been found in large numbers together with $M$. annulata.

Mallomonas papillosa var. monilifer var.nov. (Figs. 1, 2, 3; P1. 2, figs. 3-5)

Latin diagnosis. Ab typo discrepat quod scutum ex parte solum papillis obtectum: sed in iunctura scuti et cupolae sunt papillae in uno ordine curvato: cupola autem sine papillis. Cystum ferme ellipsoides.

Est unus ordo curvatus (quasi monile) papillarum.

English diagnosis. Differs from the type in scale, having only a patch of papillae on shield and in addition a single curved row of papillae where the shield adjoins the dome. The dome has no papillae. Cyst broadly ellipsoidal.

Occurrence. The var. 'monilifer' occurs in a small artificial acid pond by Farley Court (Nat. Grid, $475 \cdot 3$ E. $164 \cdot 3$ N.).

The name, 'monilifer', necklace-bearing, refers to the row of papillae.

Mallomonas papillosa var. ellipsoida var.nov. (Figs. 1-3; P1. 3, fig. 6)

History. Mallomonas papillosa Harris \& Bradley, 1960, (see Pl. 5, figs. 30, 31).

Latin diagnosis. Ab typo discrepat setis serratis validioribus: scutum squamae papillis paucioribus, superficie non ab omni parte contecta: cupola sine papillis: cystum ferme ellipticum.

English diagnosis. Differs from the type in having more strongly serrate bristles. Shield of scale with fewer papillae which do not cover the whole surface, dome without papillae. Cyst very broadly ellipsoidal.

Occurrence. The variety ellipsoida was found in the eutrophic oxbow pool at Grazely (Nat. Grid, 470.0 E. 166.8 N.). Specimens with similar scales were found and their scales seen under the electron microscope in Spencer's Wood roadside pond, but their cyst was not seen.

Discussion. Similar scales have been seen by Takahashi (1959) in Japan. The small differences are a slightly broader scale and even deeper serrations on the bristles. Mallomonas papillosa is indistinguishable from its varieties under the light microscope. Another species which looks very similar was described as $M$. radiata Conrad var. ovalis by Lund (1942, see p. 64). In my opinion forms as small as these are only to be distinguished when we have electron micrographs of the scales and bristles. 
Mallomonas papillosa may be rather like species and varieties of the 'striata' group under the light microscope. The scales of the 'striata' group are larger and more concave, and their pattern as seen with the electron microscope is completely different.

\section{Mallomonas annulata sp.nov. (Figs. 6-8; P1. 3, figs. 7-10; P1. 4, fig. 11)}

History. This species has been previously figured but its taxonomic position was not recognized. (Harris \& Bradley, 1957, text-figs. H-M; 1960, pl. 5, figs. 32, 35). It was confused with Mallomonas papillosa and referred to as M. papillosa forma annulata. Bradley (1966) raised its status to that of a variety, M. papillosa var. annulata. Further

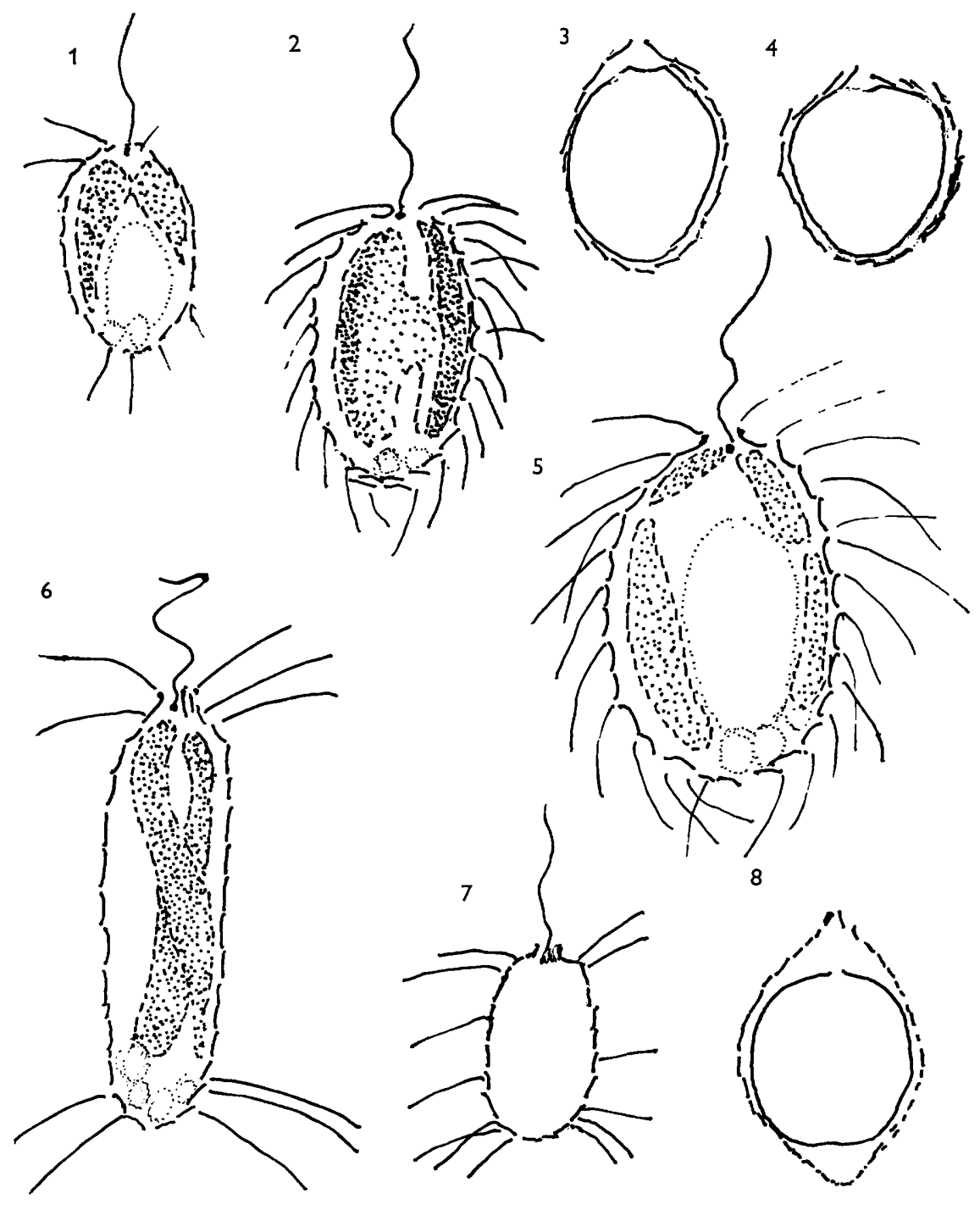

Figs. 1-8. 1, Young organism of Mallomonas papillosa. 2, Older organism of M. papillosa. 3, Cyst in mother cell of $M$. papillosa var. monilifer. 4, Cyst in mother cell of $M$. papillosa. 5, M. striata Asmund, form. 6, 7, M. annulata at different ages. 8, M. annulata cyst in mother cell. $\times 2000$ 
study has demonstrated numerous differences which are sufficient to raise it to specific rank.

Latin diagnosis. Cellula adulta elongata extremis rotundatis: sed cellula nondum adulta brevis et elliptica. Pars anterior et pars posterior, excepta parte postrema, setas ferunt: sed pars media nuda vel setis paucis sparsis. Squamae parvae trium generum: (i) squamae corporis setiferae; (ii) squamae corporis non setiferae; (iii) squamae extremae partis setiferae quoque. Squamae corporis rhomboides; setiferae cupola et scuto et margine; non setiferae scuto et margine solum. Squamae extremae partis asymmetricae. Flagellum torque circumdatum squamis corporis erectis setiferis. Squamae omnes papillis simili modo ornatae in scuto: papillae nonnunquam in circulos iunctae parte distali. Cystum leve globosum.

Dimensiones. Cellula $17-28 \times 6-10 \mu$, squamae $3-4 \times$ prope $2 \mu$, cystum $10-12 \mu$ latitudine.

English diagnosis. Mature cell elongated with rounded ends but immature cell short and ellipsoidal. Anterior and rear ends, except extreme rear, with bristles but middle region bare or with few scattered bristles. Scales small, of three kinds : body scales bearing bristles, body scales without bristles and small scales at extreme rear also without bristles. Body scales rhomboidal, those with bristles having dome, shield, and flange those without bristles having shield and flange only. Scales of extreme rear asymmetrical. Flagellum surrounded by a collar of erect body scales bearing bristles. All scales decorated on shield with similar pattern of papillae which may be joined in rings at distal end. Cyst smooth spherical.

Occurrence. Mallomonas annulata occurs in many kinds of pools-acid, eutrophic and intermediate, in the open and woods. The type locality, Stan Lake (Nat. Grid, 480.05 E. $175.5 \mathrm{~N}$.), is a slow-moving stream artificially widened. After M. akrokomos it is the commonest species near Reading and has been noticed in nearly all months of the year. Bradley (1966) has found it in Scotland and Asmund (private letter) in Denmark.

Comparison. Mallomonas papillosa and $M$. annulata are difficult to distinguish in their early stages and their small scales are very similar as seen with the light microscope, but when mature they are easy to distinguish and with the electron microscope their scales have little resemblance. Mallomonas annulata has been found in the localities of all varieties of $M$. papillosa in most months of the year. In 1957 and 1960 when Harris \& Bradley examined mallomonas scales they were in the habit of using isolated scales for the electron microscope and described $M$. papillosa, $M$. papillosa var. serrata and $M$. annulata all as $M$. papillosa, and gave light-microscope drawings of $M$. annulata (1957, pl. IV, fig. 9; 1960, pl. 5, figs. 32, 35). Further investigation has cleared up the confusion and differentiated the species.

Mallomonas striata Asmund its var. serrata Harris \& Bradley (Pl. 5, fig. 12)

Asmund (1959) described Mallomonas striata and Harris \& Bradley (1960, pl. 3, figs. 19,20 ; pl. 4, fig. 29) described a variety serrata found in a flooded field. It differed from the type in having a smaller cell and a ring of triangular collar scales not bearing bristles, and its bristles on the other scales were serrate. A second variety also having small cells and serrate bristles but without collar scales was found in a small permanent pond on acid soil (Nat. Grid, 475.3 E. 164.3 N.). Electron micrographs of several whole organisms were examined; they are not illustrated here.

Mallomonas striata has scales of rather varied ornamentation. Asmund figured and 
described several slightly different forms and I have noted other forms of scale in material from near Reading. I refrain from describing the forms as varieties from the material I have available.

\section{Mallomonas cratis Harris \& Bradley, 1960 (Pl. 5, fig. 14)}

Mallomonas cratis is interesting in showing a constant appearance with the light microscope or with the electron microscope, a constant pattern on its scales and a constant form to its bristles, though occurring in very varied waters. The type locality was a brackish pool (I did not analyse the water but it tasted very salt). It has now been found near Reading (Nat. Grid 462.0 E., 163.3 N.) in a woodland lake (Benyons Lake) on slightly acid soil. Mallomonas cratis is not unique in this respect. Mallomonopsis elliptica var. salina Asmund \& Hilliard (1965) which was first found in brackish water was also found in an inland fresh-water pool (Harris, 1966); the organisms scales and bristles from both waters look alike.

\section{Mallomonas pillula sp.nov. (P1. 5, fig. 13; P1. 6,'figs. 19-23)}

Latin diagnosis. Cellula parva globosa saepe setis contecta sed nonnunquam setis perpaucis solum. Flagellum circumdatum circulo squamarum erectarum praelongarum asymmetricarum cupola lata; squamae saepe leves vel minus valide signatae in scuto quam squamae corporis. Squamae corporis rhomboides cupola parva vel nulla. Squamae setiferae scuto et margine et cupola. Cupola levis saepe parvis foraminibus. Scutum parvis papillis signatum iunctis fascia in globos sex septem continentes, nonnunquam papillam mediam includentes. Scutum mitram ferens et fascia circumdatum punctis obliquis obscuris signata. Pars extrema distalis extra fasciam unum ordinem ferens papillarum in margine et laciniam labro revoluto. Squamae setas singulas ferentes, raro duo vel tres, leves, curvatas, breves, attenuatas. Cystum ignotum.

Forma exannulata discrepat maiores papillas ferens in scuto non in fasciam iunctas et marginem ferens distalem signatum uno ordine altarum lacunarum.

Dimensiones. Cellula prope $10 \mu$ diam., squamae prope $2 \times 1.75 \mu$.

English diagnosis. Cell small, spherical, often covered with bristles, sometimes having only a few. Flagellum surrounded by a ring of erect asymmetrically elongated scales with a broad dome, often smooth or less strongly marked on shield than are body scales. Body scales rhomboidal with small dome or no dome. Bristle bearing scales have shield, flange and dome. Dome smooth, often with some small perforations. Shield marked by small papillae joined by a band in groups of about six, sometimes enclosing a central papilla. Shield has a hood and is surrounded by a band which has oblique dark dots. Distal end, outside the band, has border with single row of papillae and flange with turned back edge. Bristles 1 , rarely 2 or 3 per scale, smooth, curved, short, tapering. Cyst unknown.

Forma 'exannulata' (P1. 6, figs. 15-18) differs in having larger papillae not joined by band, on shield, and having a distal border decorated by a single row of deep pits.

Occurrence. Mallomonas pillula and its form were found in a woodland lake on slightly acid soil, Benyons Lake (Nat. Grid, 463.0 E. 163.3 N.), in spring.

The name 'exannulata' refers to the absence of rings on the shield.

Discussion of Mallomonas pillula. Mallomonas pillula varies remarkably in the same water. One form has been described. Another form, illustrated in Pl. 6, fig. 21, has some large perforation on the basal plate while the basal plate in Pl. 6, fig. 23 has large 
perforations all over it, though the basal plate is normally smooth. The degree of annular or papillose markings is also variable. We do not know the nature of this variability but it recalls the variability one meets in naturally breeding plants in which some individuals differ genetically from others.

Bradley (1964, pl. 2, fig. 17) showed, in a specimen from Iceland, a group of scales and bristles which agree with those of a typical Berkshire specimen, and these I identify with Mallomonas pillula. In Bradley's (1964) fig. 14 there is a figure from the same locality, differing only in showing numerous minute perforations on the basal plate and striations instead of dots on the band surrounding the shield. I think this too is a form of M.pillula. I express no opinion about Bradley's fig. 13, which is of the same size and shape as M. pillula but has markings different from any I have seen; it was from a different locality and might be yet another variant.

\section{CONCLUSION}

Different kinds of variation occur in the scales of species of the genus Mallomonas. In one Mallomonas species the scales differ in anterior, middle and posterior parts of the armour, and in another species there may be differences, presumably genetical, between all the scales of one individual and of another. Harris \& Bradley (1960) showed a striking variation in scales due to their immaturity. All this variability is clearly important to the taxonomist. I feel that we shall only understand this variability deeply when it is studied in material grown in pure cultures. One subsidiary aspect of my conclusions is that I now realize that we should study whole fixed organisms, at any rate of the smaller species, with the electron microscope, as well isolated scales.

I wish to thank Professor R. W. Ditchburn, F.R.S., and Dr T. Evans for allowing me to use the electron microscope in the J. J. Thomson Physical Laboratory, Reading University, Professor P. Allen for allowing me occasional use of the electron microscope in the Geology Department, Reading University, and Mr F. Robertson, Reading University, for translating my diagnoses into Latin.

\section{REFERENCES}

Asmund, B. (1959). Electron microscope observations on Mallomonas species. Dansk bot. Ark. $18,7$. Asmund, B. \& Hilliard, D. K. (1965). Studies on the Chrysophyceae from some ponds and lakes in Alaska. Hydrobiologia 26, 521.

BradLeY, D. E. (1964). A Study of Mallomonas, Synura and Chrysophaerella of Northern Ireland. J. gen. Microbiol. 37, 321.

Bradley, D. E. (1966). Observations on some Chrysomonads from Scotland. J. Protozool. $13,143$. HARRIS, K. (1966). The genus Mallomonopsis. J. gen. Microbiol. 42, 175.

HARRIS, K. \& BRADLEY, D. E. (1957). An examination of the scales and bristles of Mallomonas in the electron microscope using carbon replicas. $J l R$. microsc. Soc. 76, 37.

Harris, K. \& Bradley, D. E. (1960). A taxonomic study of Mallomonas. J. gen. Microbiol. $22,750$.

Lund, J. W. G. (1942). Contributions to Our Knowledge of British Algae, viII. J. Bot. 80, 57.

TAKAHASHI, E. (1959). Studies on the genera Mallomonas, Synura and other plankton in fresh water by the electron microscope. I. Bull. Yamagata Univ. 3, 117. 
Journal of General Microbiology Vol. 46, No. 2

Plate 1
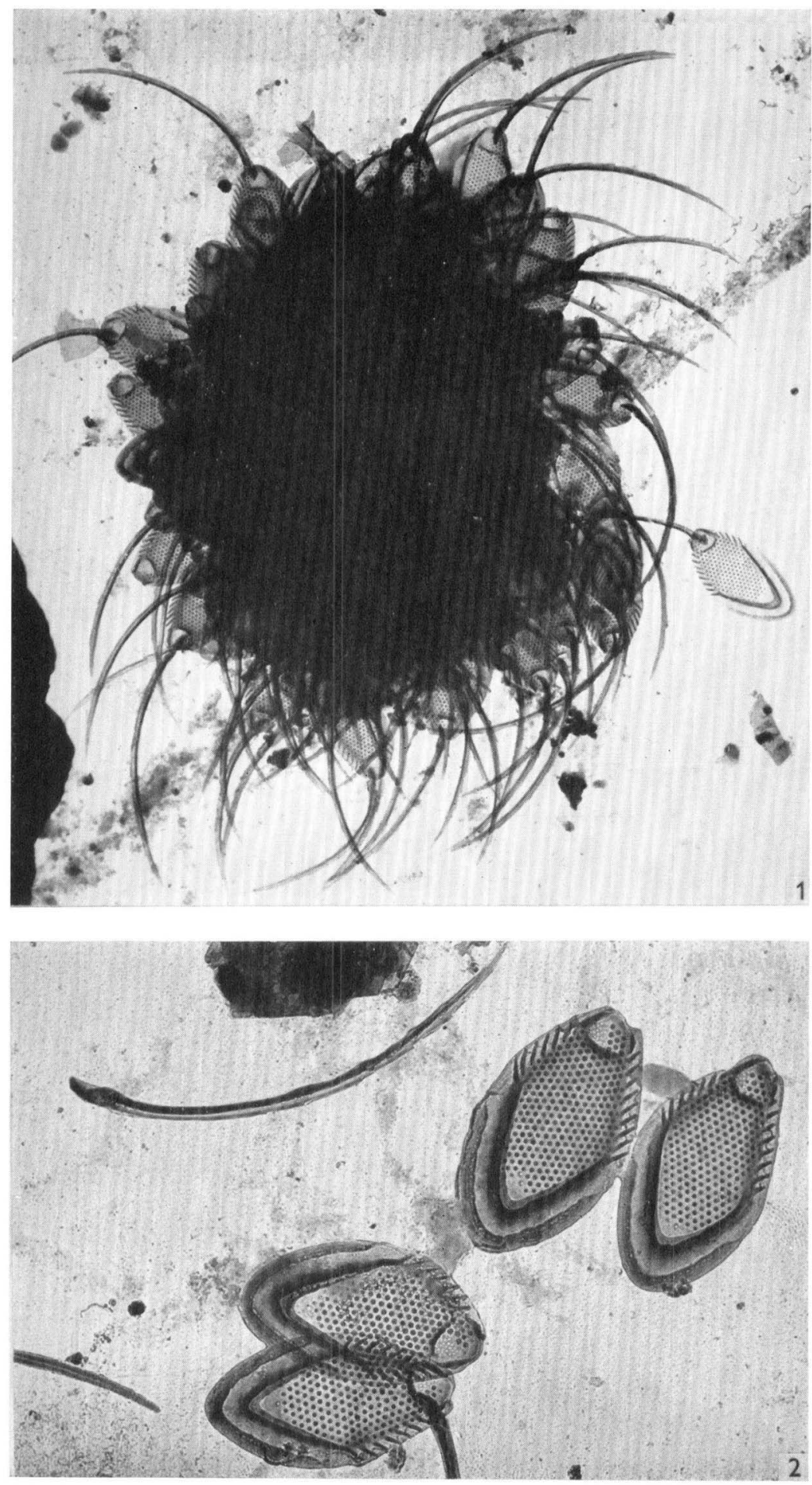

K. HARRIS

(Facing p. 190) 

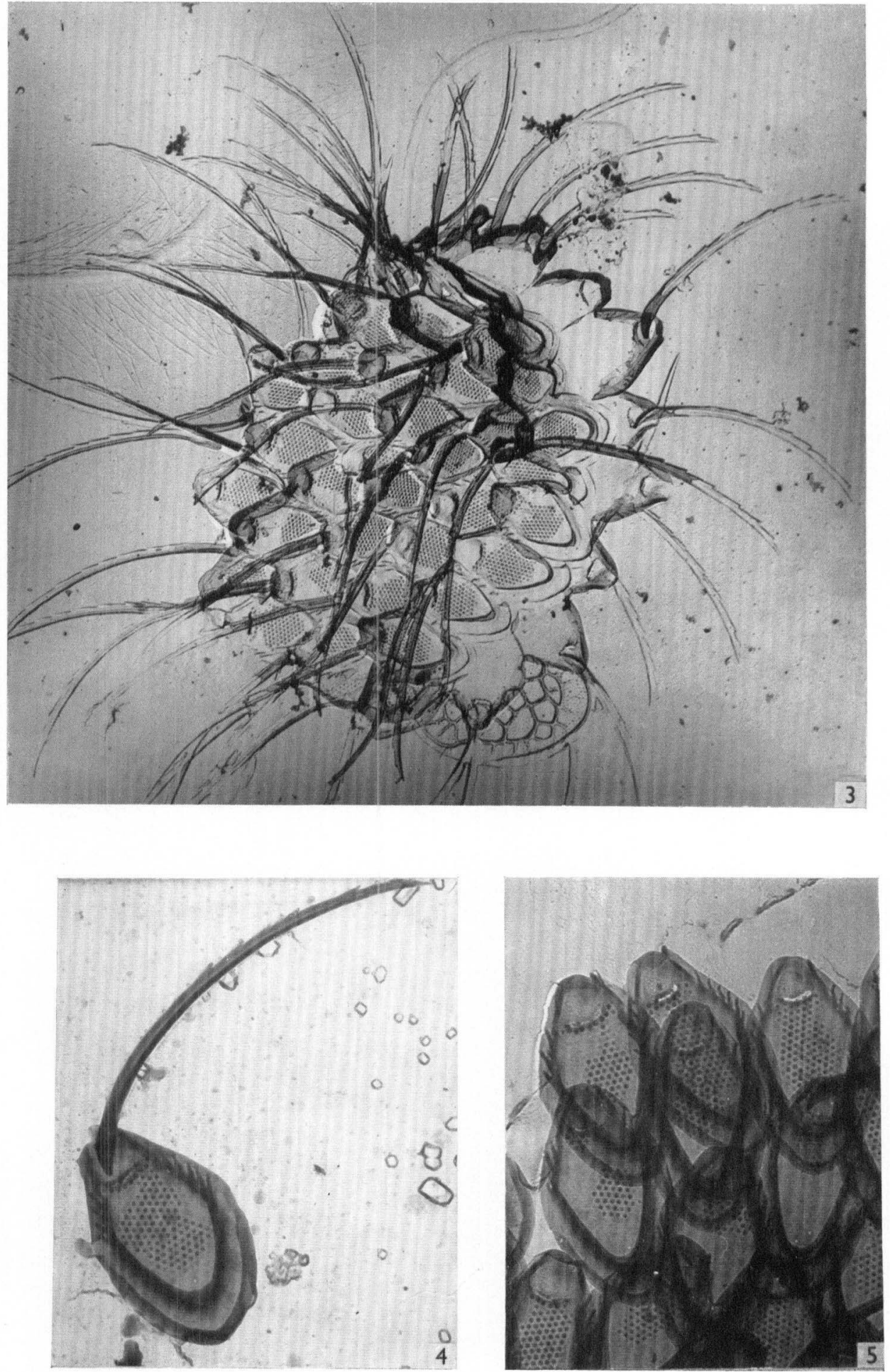

K. HARRIS 

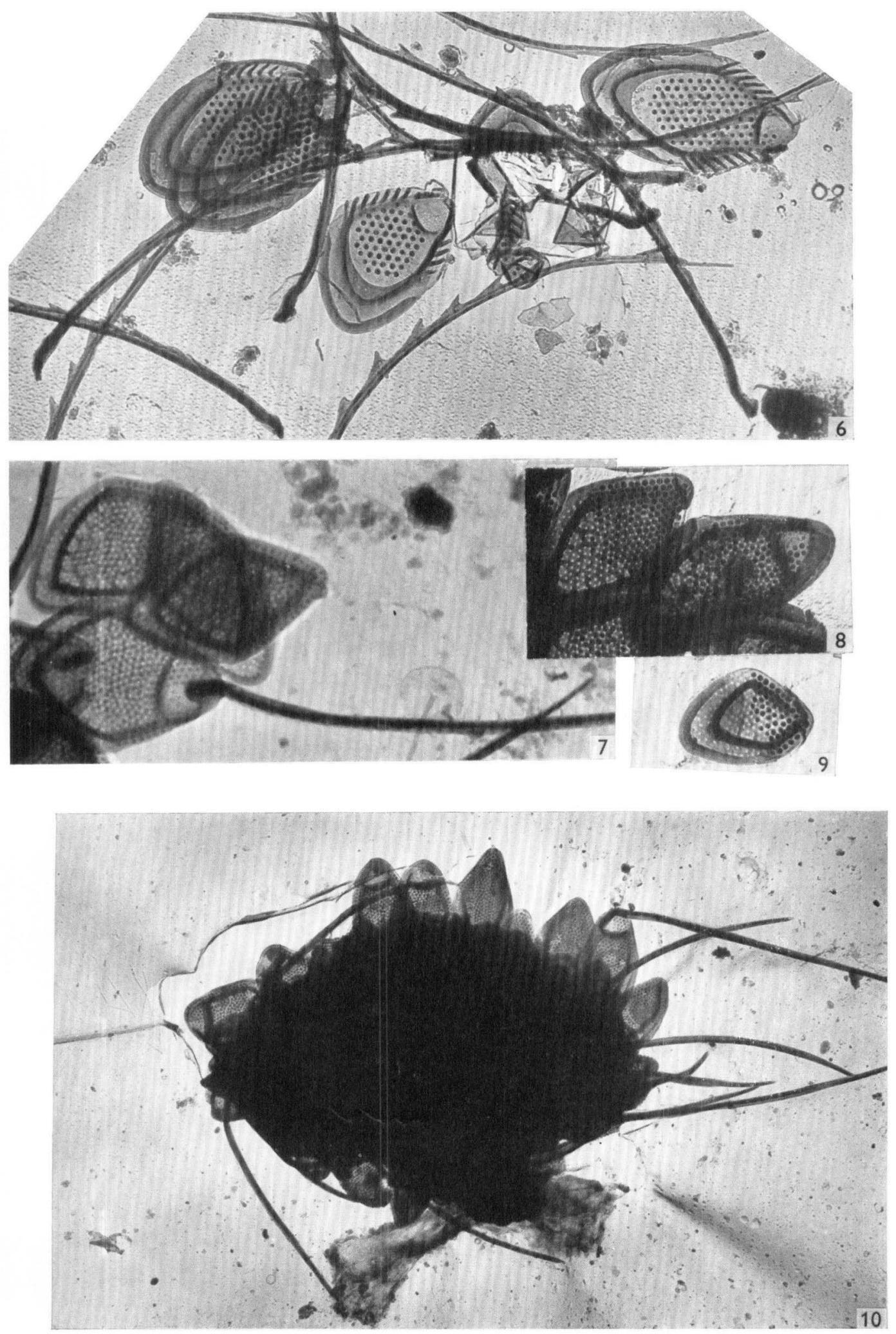

\section{K. HARRIS}




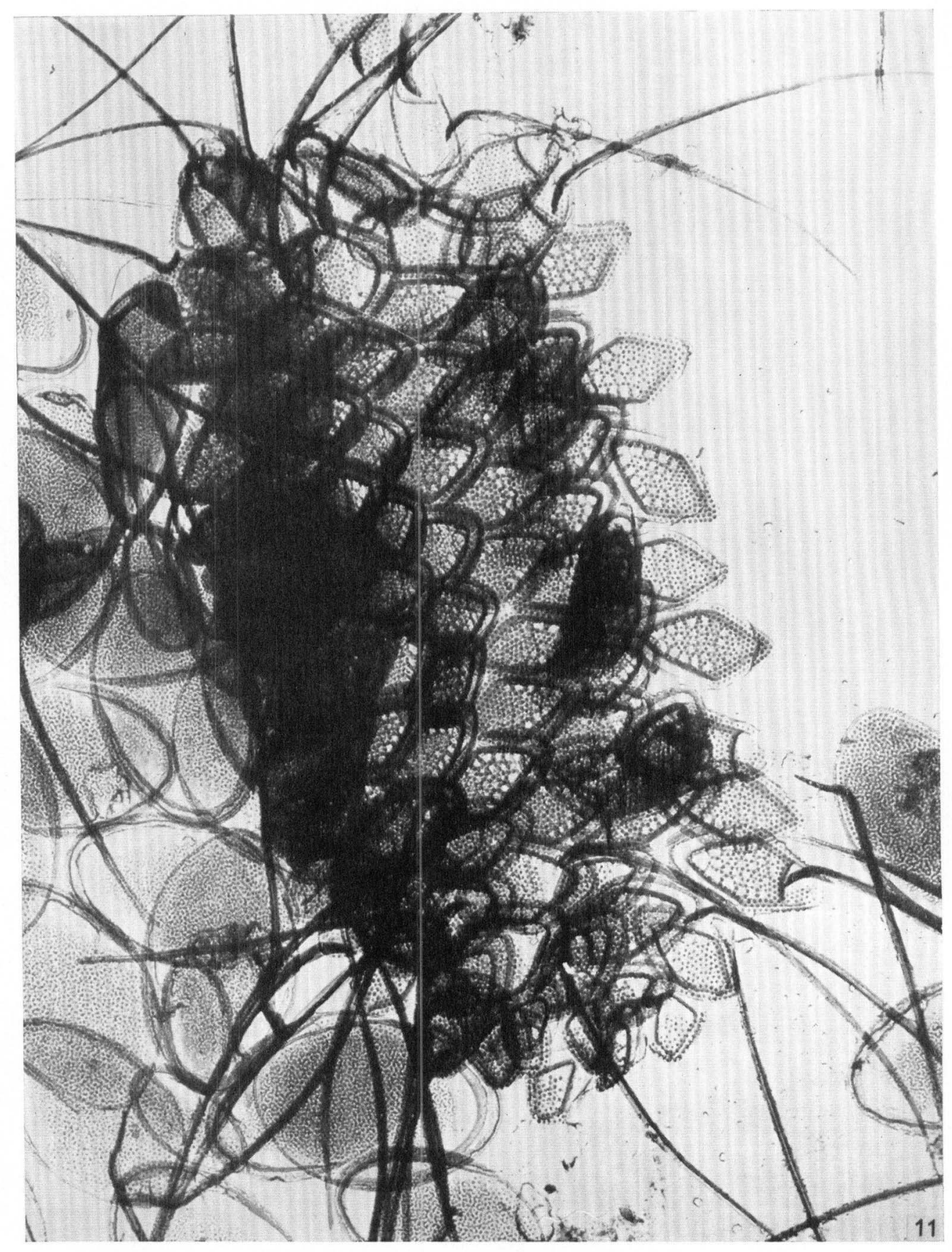

K. HARRIS 
Journal of General Microbiology, Vol. 46, No. 2

Plate 5

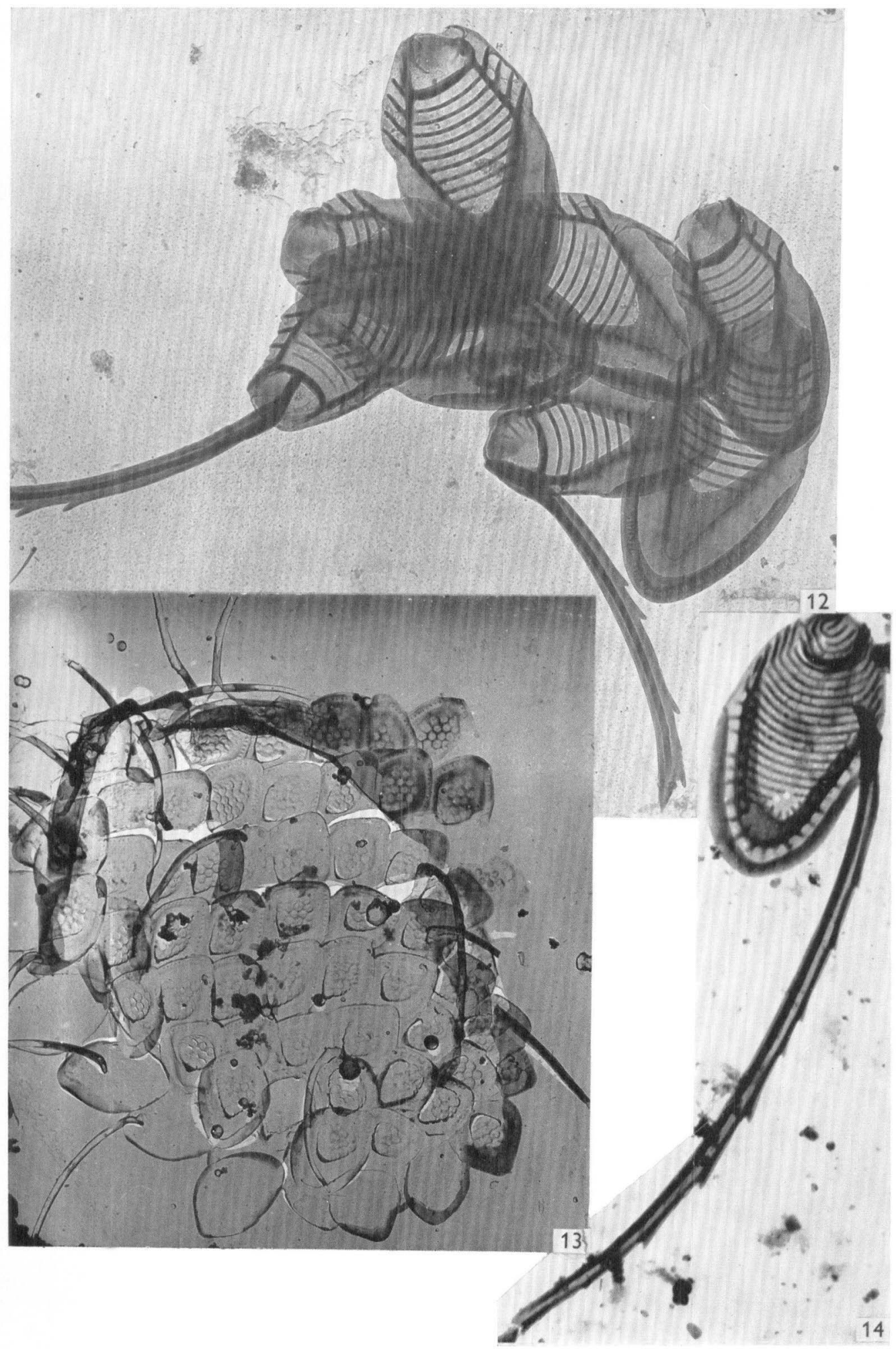

K. HARRIS 
Journal of General Microbiology, Vol. 46, No. 2

Plate 6
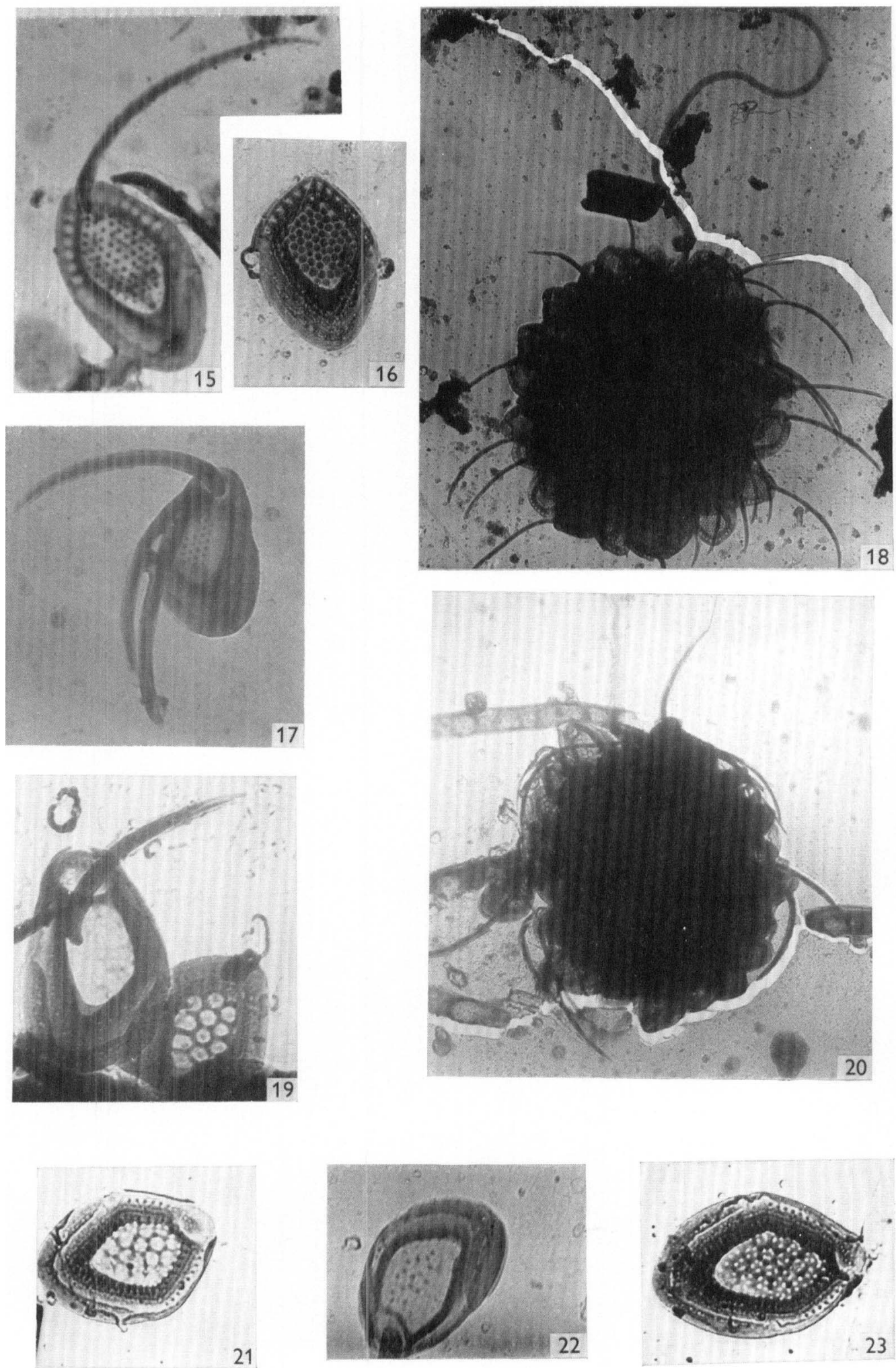

K. HARRIS 


\section{EXPLANATION OF PLATES}

Plate 1

Mallomonas papillosa

Fig. 1. Whole organism, direct. $\times 5000$.

Fig. 2. Scales and bristle, direct. $\times 1200$.

\section{Plate 2}

Mallomonas papillosa var, monilifer

Fig. 3. Mallomonas papillosa var. monilifer, whole of small cell replica; flagellum at top. $\times 5000$.

Fig. 4. Scale and bristle, direct. $\times 12,000$.

Fig. 5. Array of scales, direct. $\times 12,000$.

\section{Plate 3}

Fig. 6. Mallomonas papillosa var. elliptica, scales and bristles, direct. $\times 12,000$.

Fig. 7. Mallomonas annulata, anterior scale with dome and two without, direct. $\times 12,000$.

Fig. 8. Mallomonas annulata, rear scale with dome and one without, direct. $\times 12,000$.

Fig. 9. Mallomonas annulata, extreme rear small scale, direct. $\times 12,000$.

Fig. 10. Mallomonas annulata, whole small organism, direct. $\times 5000$.

\section{Plate 4}

\section{Mallomonas annulata}

Fig. 11. Whole organism also some scales of Mallomonopsis elliptica. var. ovalis, direct. $\times 5000$.

\section{Plate 5}

Fig. 12. Mallomonas striata form, direct. $\times 12,000$.

Fig. 13. Mallomonas pillula, replica. $\times 6000$.

Fig. 14. Mallomonas cratis, scale and bristle, direct. $\times 12,000$.

\section{Plate 6}

\section{Mallomonas pillula}

Figs. 15-18. Mallomonas pillula var. exannulata, all direct.

Fig. 15. Body scale with bristle. $\times 15,000$.

Fig. 16. Body scale. $\times 15,000$

Fig. 17. Collar scale and three bristles. $\times 15,000$.

Fig. 18. Whole organism with flagellum. $\times 5000$.

Figs. 19-23. Mallomonas pillula, all direct electron micrographs.

Fig. 19. Collar scale nearly smooth and body scale well marked, and bristle. $\times 15,000$.

Fig. 20. Whole organism with faint flagellum, direct. $\times 5000$.

Fig. 21. Body scale fairly well marked. $\times 15,000$.

Fig. 22. Collar scale faintly marked. $\times 15,000$.

Fig. 23. Body scale of a different form. $\times 15,000$. 